\title{
On the Characteristics of the Leading Dendro Flora Families Western Tenirtau (Tien Shan)
}

\author{
${ }^{1}$ Sikhymbayev A. E., ${ }^{2}$ Sikhimbayeva S. M., ${ }^{3}$ Mamykova R. U., ${ }^{4}$ Suleimenova M. T. \\ ${ }^{1}$ Silkway International University, \\ ${ }^{2}$ M. Auezov South Kazakhstan State University, \\ ${ }^{3}$ South Kazakhstan State Pedagogical University, \\ ${ }^{4}$ Miras University, Shymkent, Republic of Kazakhstan
}

\begin{abstract}
In terms of its plant richness, the Tien Shan occupies a special place among the mountain systems of Central Asia. According to many scientists, the Tien Shan is conditionally divided into three parts - western, central (inner) and northern. In the geographical nomenclature, onomastics and toponomics of modern sovereign Kazakhstan, the original name Tanirtau is used instead of the term Tien-Shan. Western Tanirtau is the most floristically rich mountain ecosystem in Kazakhstan, where the bioclimatic zones from deserts to glaciers are represented in all their diversity. The generic coefficient of the flora of Western Tanirtau is the highest in Kazakhstan and reaches 4.12, which indicates a high degree of autonomy and originality of the flora of Western Tanirtau. In terms of its plant richness, the Tien Shan occupies a special place among the mountain systems of Central Asia. According to many scientists, the Tien Shan is conditionally divided into three parts - western, central (inner) and northern. In the geographical nomenclature, onomastics and toponomics of modern sovereign Kazakhstan, the original name Tanirtau is used instead of the term Tien-Shan. Western Tanirtau is the most floristically rich mountain ecosystem in Kazakhstan, where the bioclimatic zones from deserts to glaciers are represented in all their diversity. The generic coefficient of the flora of Western Tanirtau is the highest in Kazakhstan and reaches 4.12, which indicates a high degree of autonomy and originality of the flora of Western Tanirtau.

Special report on dendroglaciological currently missing. The essence of the floristic analysis given in this paper is to identify the leading families of the dendroflora of Western Tanirtau.

The species composition of tree and shrub plants collected and recorded in all natural, anthropogenic and urbanized ecosystems of Western Tanirtau were the objects of study.

Research objectives: inventory of the species composition of the dendroflora of Western Tanirtau; compilation of the floral spectrum of the dendroflora; identification of the leading families of the region.
\end{abstract}

Keywords: dendroflora, Western Tanirtau (Tien-Shan), flora,Kazakhstan, family, genus, species.

Article Received: 16th October, 2020; Article Revised: 30th December, 2020; Article Accepted: 08th January, 2021

\section{INTRODUCTION}

The study of the dendroflora of Western Tanirtau was conducted from 2008 to 2020 . The study was conducted in the region of the Kazakh part of Western Tanirtau in the south of Kazakhstan. The collection and processing of materials was carried out according to the method of A. K. Skvortsov. All types of tree and shrub plants observed on all high-altitude mountain belts, including ridges, gorges, and anthropogenic-urbanized ecosystems, were recorded.

The analysis of the flora is based on a program of floristic research of various degrees of activity [1].

Completely new data were added to the data on the dendroflora of Western Tanirtau due to the study and analysis of the urban flora of Shymkent [2].

Nevertheless, these studies have not been deeply studied dendroflora Western Temirtau in Kazakhstan. This served as the basis for determining the current state of the natural ecosystem and the taxonomic structure of the dendroflora.

\section{STUDY AREA}

The object of study is the species composition of woody and shrubby plants 
collected and recorded in all natural, anthropogenic and urbanized ecosystems of Western Tanirtau.

According To V. N. Pavlov [3] in the natural borders of Western Tanirtau integrated climatic characteristics of naturally and clearly shows the 9 regions: I - Aksu-Dzhabagly; II - Talas-Uzunomichi; III - Badam-Keles; IV - upper Chirchik; V - Parkent; VI - Cantales-Chatkal; VII -
aflatoun-Karasu; VIII - Kurama; IX Genocidally.

The Kazakh part of the Western Tanirtau is represented within the AksuZhabagli, Talas-Uzunakhmat (partially) and Badam-Keles districts. Therefore, in the floristic analysis of the dendroflora of Western Tanirtau, we conducted a study only in these 3 districts (Figure 1).

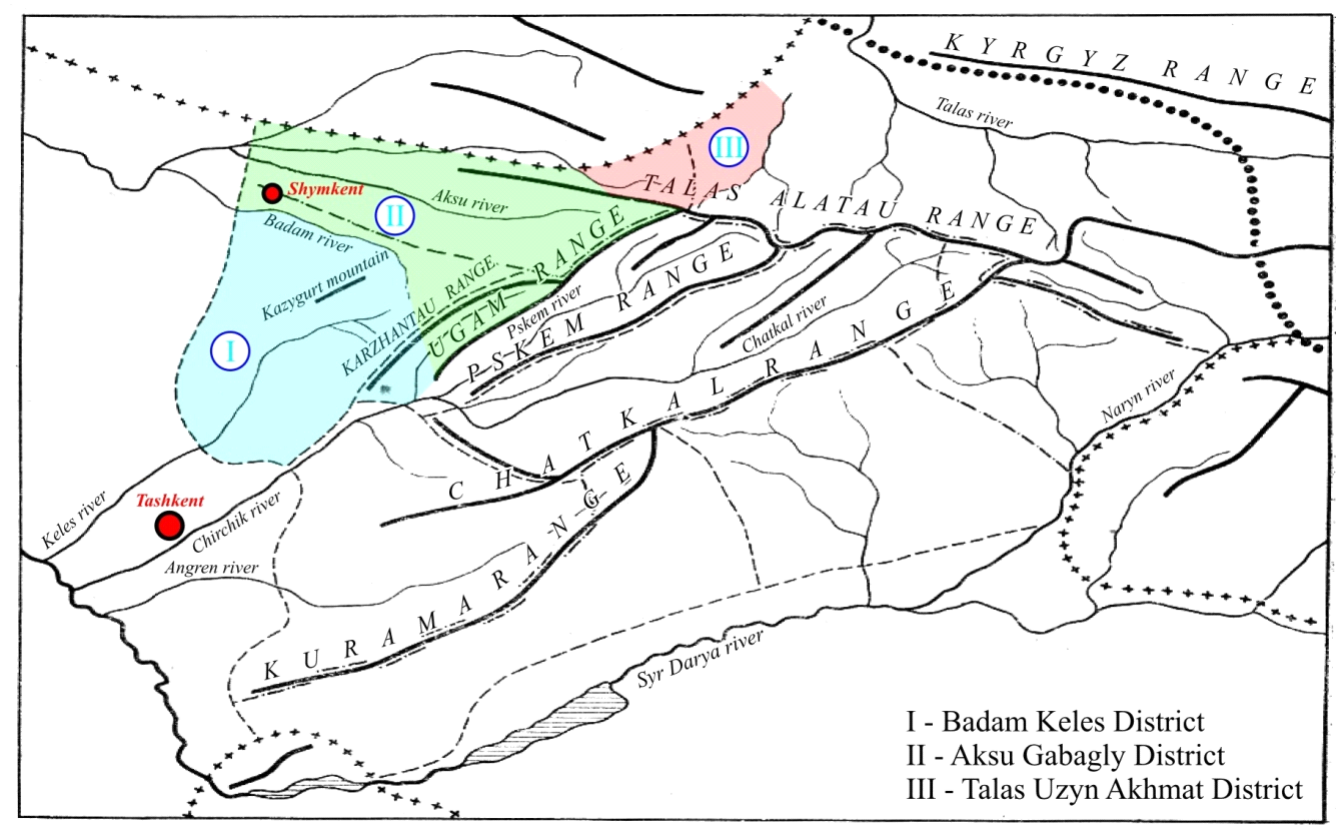

Figure 1-Map-scheme of Western Tanirtau

\section{METHODS AND MATERIALS}

The study of the dendroflora of Western Tanirtau was carried out in different seasons during numerous field trips conducted in the period from 2008 to 2020. The study was based on a summary of the dendroflora of Western Tanirtau [4].The collection and processing of the material for this work was carried out according to the generally accepted method of A. K. Skvortsov [5].

All types of tree and shrub plants observed on all high-altitude mountain belts, including ridges, gorges and agrocenoses, and anthropophytons, were recorded.

The study was carried out in the region of the Kazakh part of Western Tanirtau in the south of Kazakhstan $\left(68^{\circ} \mathrm{s}\right.$. w., $42^{\circ}$ w. d.), where the flora extends over a vast area, about 13200-13800 $\mathrm{km}$ 2(highlighted areas I, II and III in Figure 1).

The floristic analysis of dendroflora was carried out on the basis of the ecological-system approach, the theoretical aspects of which in Kazakhstan over the past 20-30 years are widely reflected in the works [6-9]. When defining the material collected during the expedition on the territory of the Western Tanirtau, and view previously collected data was stored in the Herbarium of Institute of botany and Phytointroduction of MES RK, Institute of gene pool of flora and fauna of the Academy of Sciences of the Republic of Uzbekistan identified 396 taxa dendroflora.

\section{RESULTS AND DISCUSSION OF RESULTS}


"The systematic composition of the flora, that is, the formation of certain plant species that are representatives of certain genera and families, is the main characteristic of the flora. The different combination of them in different floras allows, along with the characteristics of each of them separately, to form an idea of the similarity and difference of different floras [10]. When analyzing the composition, endemic, subendemic, and other differential taxa are singled out and considered [1]. The essence of this analysis is to identify the taxonomic structure of the flora at the level of superfamily groups, families and genera (floral, familial and generic spectra). The identification of these parameters is necessary to assess the identity of the flora and to develop a scheme of floral zoning" [11].

The average level of species richness of the dendroflora families of Western Tanirtau is 8.33 , or on average, there are slightly more than 8 species per family.The average level of ancestral wealth is 3.25 , that is, on average, there are 3 genera per family. Only in a few families of flora, the level of species richness is higher than this indicator, and an even smaller number of families approach this indicator (Table 1).

Table 1.

The leading family dendroflora Western Tanirtau

\begin{tabular}{|l|l|l|l|l|l|}
\hline o/n & Family & $\begin{array}{l}\text { Number of } \\
\text { genus }\end{array}$ & $\begin{array}{l}\text { number of the total } \\
\text { species }\end{array}$ & $\begin{array}{l}\% \text { of ther of } \\
\text { number } \\
\text { species }\end{array}$ \\
\hline
\end{tabular}




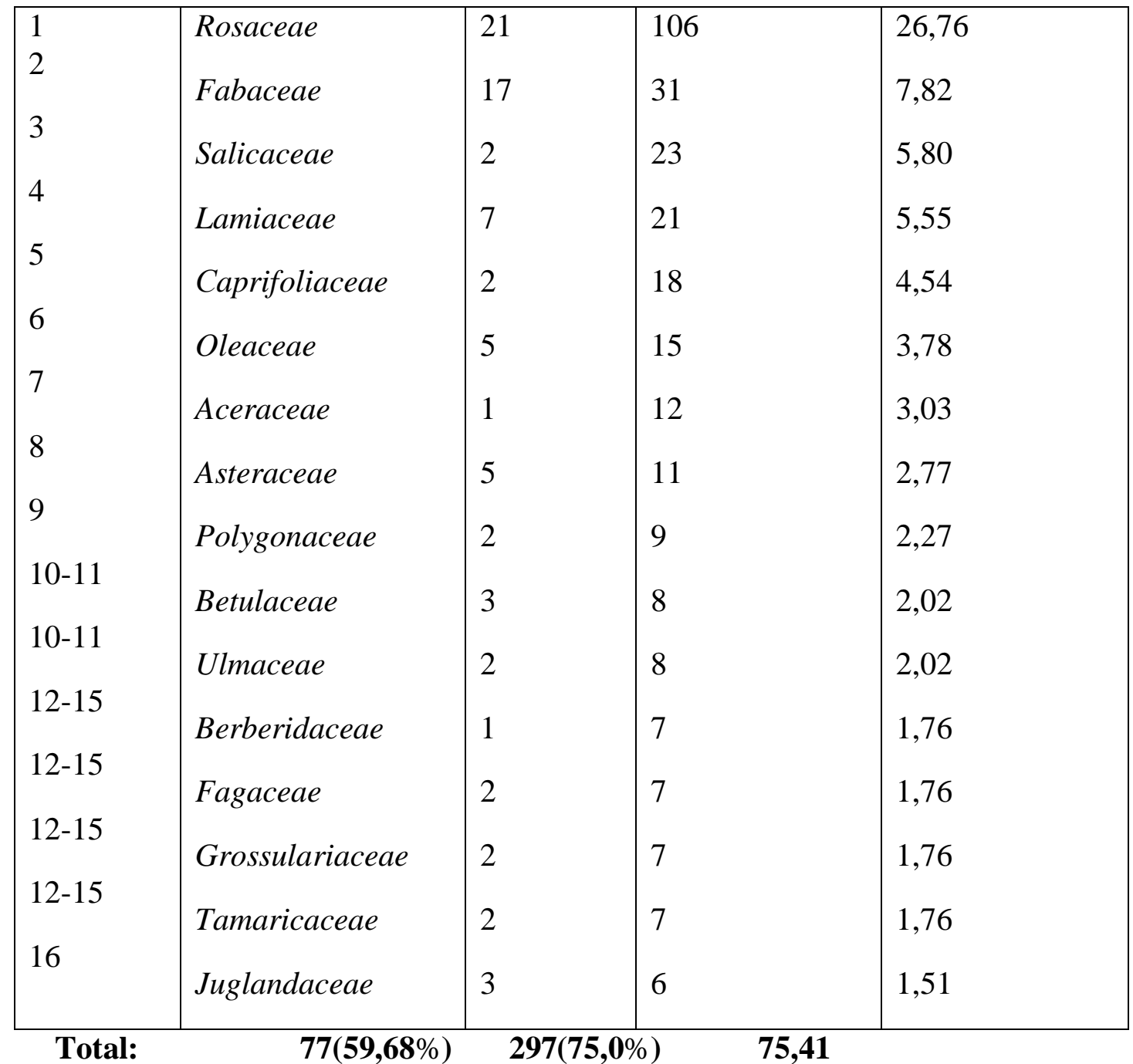

Of the 16 leading families, 5Rosaceae, Fabaceae, Caprifoliaceae, Aceraceae and Grossulariaceae represent the subclass Rosidae-Rosaceae. They contain 174 species or $43.93 \%$ of the species composition of the dendroflora of the region. The hyperpolymorphic family of the dendroflora of Western Tanirtau is Rosaceae, whose species richness exceeds the average level by 13.5 times. A very polymorphic family is Fabaceae, whose species richness exceeds the average level 4 times.

The species richness of Salicaceae, Lamiaceae, Caprifoliaceae, and Oleaceae exceeds the average by 2 to 3 times.

Let us consider these families in more detail according to M. S. Baitenov [12].

Family Rosaceae Juss. - Rosaceae

It covers about 100 genera and 3000 species, widely distributed around the globe.

There are 34 genera and 212 species in Kazakhstan [12]. Thus, only the dendroflora of the Western Tanirtau is the largest center for contemporary diversity family. Rosaceae in Kazakhstan, since 106 species of dendroflora in the region are half of the species richness of all rosaceae in Kazakhstan [12].

In the dendroflora of Western Tanirtau, 51 species out of 106 (48.11\%) are represented by cultural species from the anthropophyton.

Family Fabaceae Lindl. - Legumes

A huge family with about 700 genera and almost 17,000 species distributed around the globe.

There are 45 genera and 671 species in Kazakhstan [12:118].

In the dendroflora of Western Tanirtau, 14 species out of 31 (45.16\%) 
are represented by cultural species from the anthropophyton.

\section{Family Salicaceae Mirbel-Willow} Trees

The family includes 3 genera of about 400 species, the vast majority found in temperate regions of the Northern Hemisphere.

There are 2 genera and 68 species in Kazakhstan [12:57].

In dendroglaciological 7 species belonging to $23(30,43 \%)$ are types of cultivated ecosystems, that is, from anthropophilia.

The LamiaceaeLindl family. Clear-cut

A fairly large family, numbering more than 200 genera and about 3,500 species, with an almost cosmopolitan distribution, but especially numerous - in the countries of the Mediterranean, Western and Central Asia.

There are 49 genera and 247 species in Kazakhstan [12:176].

Made up of dendrites in the Western Tanirtau, all 21 species observed in natural ecosystems.

The Capriforliaceae Juss family. -

\section{Honeysuckle}

There are about 15 genera in the family, with more than 250 species, distributed mainly in the temperate and subtropical zones of the Northern Hemisphere.

There are 4 genera and 25 species in Kazakhstan [12: 192],

In the dendroflora of the Western Tanirtau, 9 species out of $18(55.55 \%)$ are represented by species from cultivated ecosystems, that is, anthropophyton.

The Oleaceae Hoffm family. - Olives

The family includes up to 25 genera and about 600 species, found in tropical, subtropical and partly temperate regions of both hemispheres.

There are 2 genera and 3 species in Kazakhstan [12: 164 ].

In the dendroflora of Western Tanirtau, 14 species out of 15 (93.33\%) are represented by species from the anthropophyton.

Family Aceraceae Juss - - Maple trees

The family consists of 2 genera and more than 120 species, distributed mainly in the northern hemisphere, and only a few species are found in the tropics.

Kazakhstan has 1 genus with 7 species [12: 133].

In the Dendroflora of the West of Kazakhstan, 10 out of 12 species (83.33\%) are representatives of the anthropophyton.

Family Asteraceae Dumort. - Aster trees

One of the largest families of the plant world of the Earth. It has more than 1,500 genera and more than 20,000 species, widely distributed around the globe.

In Kazakhstan, the family is represented by 146 genera and 883 species [12: 199].

In the Dendroflora of the West of the city of Aktau, all 11 species are represented from natural ecosystems.

Family Polygonaceae Juss - Buckwheat

The family includes about 45 genera and 800 species, distributed almost all over the globe, but especially numerous in the Northern Temperate zone.

There are 11 genera and 141 species in Kazakhstan [12: 64].

In the Dendroflora of the West of the city of Aktau, all 9 species are representatives of natural ecosystems.

Family Betuluceae S. F. Gray-Birch

The family includes 6 genera and about 150 species, distributed mainly in all temperate, extratropical regions of the Northern Hemisphere.

There are 2 genera and 16 species in Kazakhstan [12:59].

In the dendroflora of Western Tanirtau, 6 out of 8 species $(75 \%)$ are represented by species from the anthropophyton.

\section{Family Ulmaceae Mirbel - Elm}

The family includes 8 genera and about 50 species, distributed from temperate regions to the tropics of the 
Northern Hemisphere.

Kazakhstan has 1 genus with 5 species [12: 61].

Made up of dendrites in the Western Tanirtau 8 kinds of $7(87,50 \%)$ represented antropologica.

\section{Family Berberidaceae Juss - - Barberry}

The family includes about 15 genera and 650 species, distributed mainly in the temperate and subtropical regions of the Northern Hemisphere.

There are 4 genera and 13 species in Kazakhstan [12: 90]

In the Dendroflora of the West of Kazakhstan, 3 out of 7 species $(42.85 \%)$ are representatives of the anthropophyton.

Family Fagaceae Dumort. - Beech trees

The family includes 9 genera and more than 900 species distributed in temperate, subtropical and tropical regions of both hemispheres.

There is 1 genus with one species in Kazakhstan [12: 60].

In dendroglaciological all 7 types (100\%) represented anthropophilia.

Family Grossulariaceae DC. Gooseberries

The family includes 23 genera and more than 150 species distributed in the temperate and subtropical regions of the Northern Hemisphere, a number of species found in the mountainous regions of Central and South America.

There are 2 genera and 12 species in Kazakhstan [12:111]

In the Dendroflora of the West of Kazakhstan, 4 out of 7 species $(57.14 \%)$ are represented by species of cultivated ecosystems of the anthropiphoton.

Family Tamaricaceae Link. Grebenshchikov
The family includes 4 genera and about 90 species, distributed on the coast of salty reservoirs in subtropical and moderately warm regions of both hemispheres.

There are 4 genera and 21 species in Kazakhstan [12:138].

In the dendroflora of Western Tanirtau, 4 out of 7 species $(57.14 \%)$ were recorded in cultivated landscapes of the anthropophyton Nutty

The family Juglandaceae Rich. -

The family includes 7 genera and about 60 species distributed in temperate and subtropical regions of the Northern Hemisphere.

Kazakhstan has 1 genus with 2 species [12:58]

Made up of dendrites in the Western Tanirtau 6-5 (83,33\%) represented anthropophilia.

In the above-mentioned 16 families, three-quarters $(75.41 \%)$ of the total species composition of the dendroflora of the studied region is concentrated. Therefore, we can assume that the most general characteristics and trends can be drawn from the analysis of the family spectrum of the dendroflora of Western Tanirtau (Table $1 ; 2)$.

According to Table 2, of the 16 leading dendroflora families in the region, the centers of species richness of 8 families can be said to be "southern": that is, they are located in areas of warmtemperate and subtropical, some even tropical zones. Among them, only the Lamiaceae family is fully represented by natural species.

Table 2.

Some characteristics of the family spectrum of the

dendroflora of Western Tanirtau 


\begin{tabular}{|c|c|c|c|c|}
\hline Families & $\begin{array}{l}\text { Saturation of } \\
\text { genera and } \\
\text { species in } \\
\text { the } \\
\text { arboretum. } \\
\text { West. } \\
\text { Tanirtau(nu } \\
\text { mber of } \\
\text { gemus/ } \\
\text { number of } \\
\text { types) }\end{array}$ & $\begin{array}{l}\% \text { the } \\
\text { proportion } \\
\text { of types of } \\
\text { anthropo- } \\
\text { the fiton } \\
\text { Tanirtau } \\
\text { (in } \%)\end{array}$ & $\begin{array}{l}\text { Content. genera } \\
\text { and species in } \\
\text { the nature of } \\
\text { Kazakhstan } \\
\text { (according to } \mathrm{M} \text {. } \\
\text { Baitenov[4] } \\
\text { (number of } \\
\text { genera/number } \\
\text { of species) }\end{array}$ & $\begin{array}{l}\text { General geography of } \\
\text { families (according to } \mathrm{M} \text {. } \\
\text { Baitenov [4]) }\end{array}$ \\
\hline 2 & 3 & 4 & 5 & 6 \\
\hline Rosaceae & $21 / 106$ & 48,11 & $34 / 212$ & Cosmopolitan \\
\hline Fabaceae & $17 / 31$ & 45,16 & $45 / 617$ & Cosmopolitan \\
\hline Salicaceae & $2 / 23$ & 30,43 & $2 / 68$ & $\begin{array}{l}\text { Temperate regions of } \\
\text { the north. hemispheres }\end{array}$ \\
\hline Lamiaceae & $7 / 21$ & - & $49 / 247$ & $\begin{array}{l}\text { Moderate-hot } \\
\text { subtropical regions. }\end{array}$ \\
\hline $\begin{array}{l}\text { Caprifoli- } \\
\text { aceae }\end{array}$ & $2 / 18$ & 55,55 & $4 / 25$ & $\begin{array}{l}\text { Tempered glass. and } \\
\text { subtropical region of } \\
\text { the } \\
\text { hemisphere }\end{array}$ \\
\hline Oleaceae & $5 / 15$ & 93,33 & $2 / 3$ & $\begin{array}{l}\text { Tempered glass. warm, } \\
\text { subtropical, and } \\
\text { tropical regions }\end{array}$ \\
\hline Aceraceae & $1 / 12$ & 83,33 & $1 / 7$ & $\begin{array}{l}\text { Temperate regions of } \\
\text { the north. hemispheres }\end{array}$ \\
\hline Asteraceae & $5 / 11$ & - & $146 / 883$ & Cosmopolitan \\
\hline $\begin{array}{l}\text { Polygona- } \\
\text { ceae }\end{array}$ & $2 / 9$ & - & $4 / 11$ & $\begin{array}{l}\text { Temperate regions of the } \\
\text { north. hemispheres }\end{array}$ \\
\hline Betulaceae & $3 / 8$ & 75,0 & $2 / 16$ & $\begin{array}{l}\text { Temperate regions of the } \\
\text { north. hemispheres }\end{array}$ \\
\hline Ulmaceae & $2 / 8$ & 87,50 & $1 / 15$ & $\begin{array}{l}\text { Tempered glass. and } \\
\text { subtropical region. }\end{array}$ \\
\hline $\begin{array}{l}\text { Berberi- } \\
\text { daceae }\end{array}$ & $1 / 7$ & 42,85 & $4 / 17$ & $\begin{array}{l}\text { Tempered glass. and } \\
\text { the sub-region of the } \\
\text { north. hemispheres }\end{array}$ \\
\hline Fagaceae & $2 / 7$ & 100 & $1 / 1$ & $\begin{array}{l}\text { Tempered } \\
\text { and glass. warm } \\
\text { regions. }\end{array}$ \\
\hline $\begin{array}{l}\text { Grossula- } \\
\text { riaceae }\end{array}$ & $2 / 7$ & 57,14 & $2 / 12$ & $\begin{array}{l}\text { Tempered glass. and } \\
\text { subtropical region. }\end{array}$ \\
\hline
\end{tabular}




\begin{tabular}{|l|l|l|l|l|l|}
\hline & $\begin{array}{l}\text { Tamari- } \\
\text { caceae }\end{array}$ & $2 / 7$ & 57,14 & $4 / 21$ & $\begin{array}{l}\text { Tempered glass. warm } \\
\text { and subtropical } \\
\text { regions. }\end{array}$ \\
\hline & $\begin{array}{l}\text { Juglan- } \\
\text { daceae }\end{array}$ & $3 / 6$ & 83,33 & $1 / 2$ & $\begin{array}{l}\text { Tempered glass. warm } \\
\text { and subtropical } \\
\text { regions. }\end{array}$ \\
\hline
\end{tabular}

In general, according to the general geographical characteristics, the leading dendroflora families of Western Tanirtau can be divided into three conditional groups:

I. Widespread (cosmopolitan)

II. "North"

III. " South»

Group I consists of the families Rosaceae, Fabaceae, Asteraceae, which includes 43 genera and 148 species. This is $33.33 \%$ of the generic composition and $37.37 \%$ of the species composition of the entire dendroflora of Western Tanirtau.

The peculiarity of this group is that it contains hyperpolymorphic Rosaceae and very polymorphic Fabaceae. The proportion of types of anthropophyton in this group ranges 45,16 - 48,11\%. Only Asteraceae is fully represented by natural species. These percentages indicate that in Western Tanirtau there is a noticeable enrichment of the plant gene pool by representatives of the Rosaceae and Fabaceae families [13-16].

Group II consists of the families Salicaceae, Aceraceae, Polygonaceae and Betulaceae, which includes 8 genera and 52 species. This is $6.20 \%$ of the generic composition and $13.13 \%$ of the species composition of the studied dendroflora. In this group, only Polygonaceae does not have anthropophyton species in its composition. And in the other families, the proportion of anthropophyton species ranges from $30.43 \%$ (Salicaceae) to 83.33 $\%$ (Aceraceae). Of course, the degree of enrichment of the gene pool of the flora of the region in this group is significantly higher than in the previous "cosmopolitan group" [17-20].

Group III is represented by the families Lamiaceae, Caprifoliaceae,
Oleaceae, Berberidaceae, Ulmaceae, Grossulariaceae, Fagaceae, Tamaricaceae, Juglandaceae and combines $20.15 \%$ of the generic composition and $24.49 \%$ of the species composition of the entire dendroflora of Western Tanirtau. In this group, only one family, Lamiaceae, is fully represented by natural species. And in the other families, the proportion of anthropophyton species ranges from $42.85 \%$ (Berberidaceae) to $100 \%$ (Fagaceae) [21,22,23].

The high representativeness of both families and genera and the very high percentage of anthropophyton species indicate that the enrichment of the plant gene pool mainly comes from the south. This once again indicates that the expansion of southern, subtropical elements is confirmed [24].

\section{CONCLUSIONS}

During the analysis of materials collected on the territory of Western Tanirtau and viewing previously collected materials, 396 dendroflora taxa belonging to 130 genera and 50 families were identified. The proposed material is an actual reflection of the current state of the dendroflora of Western Tanirtau within Kazakhstan and for the first time the leading families of woody and shrubby plants are identified at the current level of taxonomy and nomenclature. For the first time, the most complete list of dendroflora of the West of the city of Aktau is given, which includes 396 species of woody and shrubby plants.

The proposed material is an actual reflection of the current state of the dendroflora of Western Tanirtau within Kazakhstan.

The data presented in the article are 
recommended for use in the preparation of the Kazakhstan National Strategy for the Conservation and Balanced Use of Biological Diversity, and are considered for inclusion in the"Plant Determinant of the Republic of Kazakhstan". The complete list of species is recommended for use in the compilation of the Plant Identification Index of the surroundings of the city of Shymkent, as well as in the theoretical analysis of the flora of Western Tanirtau. In addition, we offer the results of the study for use in the development of resource and environmental measures in the region.

\section{Literature}

1. Юрцев Б. А., Камелин Р. В.Теоретические и методические проблемы сравнительной флористики: Материалы II рабочего совещания по сравнительной флористике. Неринга, 1983. // Отв. редактор Б.А.Юрцев. - Л.: Наука, 1987. -283 с.

2. Сихимбаева С.M. Шымкент қаласының урбанофлорасы. Шымкент, 2014. -184 б.

3. Павлов В.Н. Растительный покров Западного Тянь-Шаня, М.: МГУ, 1980. 248 c.

4 Сихымбаев А.Е. Материалы к дендрофлоре Западного Таниртау: монография. - Шымкент, 2017. - 122 с.

5. Скворцов А.К. Гербарий. Пособие по методике и технике.-М.: Наука, 1977.- 198 с.

6. Байтулин И.О. Состояние и перспективы охраны растений Казахстана // Охрана редких видов растений и растительности Казахстана Алматы : Наука - 1987. - с.319.

7. Байтулин И.О. Гармонизация проблем экономики и экологии в развитии общества // Известия НАН РК.-сер. Б. биол.-1993, №1.

8. Байтулин И.О. Системный подход к сохранению и сблансированному

использованию

биологическогоразнобразия //

Республ. семин.

«Подгодовительный этап

разработки Нац.стратегии и

плана действий сохранения и

сбалансированного

использования биологического разнообразия» - Алматы, 1996. - c.12-23.

9. Байтулин И.О., Курочкина Л.Я., Аралбаев А.К. и др. Национ. прог. действ. по борьбе с опустыниванием в РК (НПДБО)

(Расширенный реферат) - Алматы. -1996. 31c.

10. Толмачев А.И. Методы сравнительной флористики и проблемы флорогенеза. Новосибирск: «Наука», 1986. $195 \mathrm{c}$.

11. Малышев Л.И. Современные подходы к количественному анализу и сравнению флор // Теоретические и методические проблемы сравнительной флористики: Материалы 2 рабочего совещания по сравнительной флористики. Л.: Наука. 1987. С. 142-149.

12. Байтенов М.С. Флора Казахстана. Т.1. -Алматы, 2001; T.2.-2002.

13. Сихымбаев Ә.Е., Садықова Ж.С., Шыңғысбаева В.Қ., Куандықова Г.O. Rosaceae Juss. $\quad$ тұқымдасы дендрофлорасының алуан түрлілігі. // «Өсімдіктер әлемі және оны қорғау», Алматы, 2007.

14. Сихымбаев Ә.Е., Сихымбаева C.M. Дендрофлораның шаруашылық маңызы. // «Білім, ғылым және өндірістің өзекті мәселелері», II том, Шымкент, 2007.

15. Сихымбаев Ә.Е., Сихымбаева 
C.M., Жақсыбаева Y.C. Қаржантау жотасындағы Fabaceae тұқымдасы дендрофлорасына қысқаша шолу. // «Білім, ғылым және өндірістің өзекті мәселелері», II том, Шымкент, 2007.

16. Сихымбаев Ә.Е., Баймұратова Г.И. Rosaceae Juss. тұқымдасы дендрофлорасының

ерекшелігі. // «Білім мен ғылымның болашағы»"), Шымкент, 2007.

17. Сихымбаев Ә.Е., Софиева A.A. Salicaceae Lindl. тұқымдасына флористикалық талдау.// «Білім мен ғылымның болашағы», 2007.

18. Сихымбаев Ә.Е., Алтыбаева Қ.С.Қаржантау жотасы фанерофиттерінің экологиялық жағдайы. // X - студенттік ғылыми-практикалық конф. Шымкент, 2008.

19. Сихымбаев Ә.Е.,Төребекова Б.Т. Біркөлік шатқалы дендрофлорасының

макрофанерофиттері. // X студенттік ғылымипрактикалық конф. Шымкент, 2008.

20. Сихымбаев Ә.Е., Аралбай Н.К., Шыңғысбаева В.Қ. Батыс Тәңір тауының Salicaceae Lindl. тұқымдасы туралы. Научный журнал «Ізденіс/Поиск». Алматы, 2008.№4.

21. Сихымбаев Ә.Е., Сихымбаева C.M., Садықова Ж.С.Батыс Тәңір тауының физикалық және географиялық табиғи жағдайы. Научный журнал «Ізденіс // Поиск». Алматы, 2008.№4.

22. Сихымбаев A.Е., Мырзакаримова Х.Д. Реликтовые и исчезающие виды дендрофлоры Западного Тянь-Шаня. Научный журнал
"Узбекский Биологический Журнал», Ташкент, №4 - 2009.

23. Сихымбаев Ә.Е., Әуелова Ж.К.,Сихымбаева С.М. Предварительный анализ дендрофлоры ущ. Бургулюк (Западный Тянь-Шань). // «Aktualni vymozenosti vedy», София, 2012.

24. Аралбай Н.К, Иманбаева А.А. Актуальные вопросы интродукции растений в аридной зоне Современного Казахстана. - // «Интродукция растений, сохранение биоразнообразия и земли строительство в аридных регионах». - Актау, 2012. c.23. 